\title{
AN INVESTIGATION INTO THE RELATIONSHIP BETWEEN ANAEROBIC WORK CAPACITY, PERCENTAGE BODY FAT AND THE GRADE OF ASTHMA IN ASTHMATICS AND A HEALTHY CONTROL GROUP
}

\section{Burger, M Geyer, W Regel, G M Smit, E Terblanche and J A Hendry}

\begin{abstract}
SUMMARY
The goal of this study was to compare the anaerobic working capacity of asthmatic children to that of a healthy control group and to ascertain the relationship between the degree of asthma, anaerobic exercise and percentage body fat.

A total of 41 children, 21 asthmatics and 20 healthy children (13-18 years) were tested. Three variables - percentage body fat, pulmonary function and fitness - were measured. It was found that there is very little difference between the asthmatic and the healthy child, with regard to anthropometric measurements, fitness and anaerobic working capacity. A poor correlation was found between percentage body fat, pulmonary function and anaerobic working capacity. The results further showed that there is a slight correlation between the percentage body fat and anaerobic working capacity. This tendency can only be confirmed with a larger random sample of children.

The researchers conclude that asthmatics, irrespective of the degree of asthma, are not restricted as far as anaerobic activities are concerned. They can therefore lead a normal healthy life and, as far as anaerobic exercise is concerned, can compete on equal terms with healthy children.
\end{abstract}

\section{INTRODUCTION}

The physiotherapy profession is growing increasingly interested in exercise-induced bronchospasm (EIB) because eighty percent of all asthmatics develop EIB .

Most research deals with the cardio-respiratory fitness of asthmatics while most experimental groups consist of patients witl chronic obstructive pulmonary disease or heterogeneous patients with obstructive airway disease ${ }^{2,3,45}$. The researchers noted that there was a definite deficiency in the literature providing a well controlled study of a homogeneous group of patients and an ageequivalent control group. The fact that such a large percentage of children suffer from asthma served as motivation for the use of schoolgoing children in this study.

Since the anaerobic working capacity of asthmatics had not. been previously documented, the question arose whether asthmatics suffered the same limitations with anaerobic exercise as with aerobic exercise. It was also not known whether the degree of asthma and the physical build were limiting factors for anaerobic working capacity.

\section{LITERATURE REVIEW}

Approximately $18 \%$ of all children, 18 years and younger.

\section{OPSOMMING}

Die doel van die studie was om die anaërobiese werkkapasiteit van asmalyers en 'n gesonde kontrole groep te vergelyk en om die verband tussen die graad van asma, anaërobiese werkkapasiteit en persentasie liggaamsvet te ondersoek.

'n Totaal van 41 kinders (21 asmalyers en 20 gesonde kinders), tussen die ouderdom 13-18 jaar is getoets. Drie veranderlikes persentasie liggaamsvet, pulmonêre funksie en fiksheid - is gemeet

Daar is min verskille t.o.v. antropometrie en fiksheid tussen die asmalyers en die gesonde kontrole groep gevind. Die anaërobiese werkkapasiteit van die asmalyers en die kontrole groep het nie verskil nie en daar was 'n swak korrelasie tussen die persentasie liggaamsvet, pulmonêre funksie en anaërobiese werkkapasiteit. Die resultate toon voorts dat daar ' $n$ klein waarskynlikheid is dat daar 'n verband bestaan tussen persentasie liggaamsvet en anaërobiese werkkapasiteit, asook dat asmalyers geneig is tot ' $n$ hoër persentasie liggaamsvet. Hierdie tendens kan egter net met 'n groter steekproef bewys word.

Die navorsers het tot die gevolgtrekking gekom dat asmalyers, ongeag die graad van asma, nie beperkinge ervaar t.o.v. anaërobiese tipe aktiwiteite nie en dus met gesonde kinders op gelyke vlak kan kompeteer.

experience some form of chronic respiratory dysfunction at some stage. Four percent of these children are asthmatics ${ }^{6}$.

According to the literature $2-6 \%$ of the world population suffers from bronchial asthma ${ }^{7}$, while $60-80 \%$ of all asthmatics also suffer from EIB. From this it can be seen that at least $5 \%$ of the world population of asthmatics also develops bronchospasm with exercise? In 1988 it was found that $6.5 \%$ of whites and $3,5 \%$ of coloureds between 6 and 18 years - in the northern suburbs of Cape Town suffered from ElB ${ }^{4}$.

Most asthmatics develop a noticeable degree of bronchospasm as a result of exercise, which greatly restricts their extramural activities and sport and can lead to social and psychological problems. Exercise induced bronchospasm (EIB) is not related to age, sex or the degree of asthma ${ }^{8}$. It is found in patients with or without a positive skin test. In some asthmatics EIB is the only form of asthma whiçh they experience.

In 1976 it was found that, while a raised fitness level did not necessarily free the asthmatic from EIB, it could well lead to an improved physical work capacity ${ }^{7}$. In 1989 asthmatics (at age 25) were found to have a higher $\mathrm{VO}_{2}$ maximum (maximal oxygen volume) and a normal work capacity on maximum work loading if they had followed a regular exercise programme from a early age (approximately 10 years). This could be due to an earlier exposure to an exercise programme or to a higher motivation? 
To date nearly all research has been aimed at the effect of aerobic exercise programmes on the cardiorespiratory function of patients with chronic obstructive airway disease. Most studies have shown the advantage of exercise programmes ${ }^{10,11,1213}$, while other researchers have established aerobic exercise programmes to test cardiorespiratory fitness 12,14 .

As far as can be ascertained, the anaerobic work capacity of asthmatics has not yet been studied. Since ordinary activities are mainly anaerobic in nature, it is important to know how far asthmatics are limited with these. Acute asthmatics, for whom aerobic activities lead to severe bronchospasm, might possibly also benefit from anaerobic types of activity.

\section{METHOD}

\section{Hypothesis}

The anaerobic work capacity of asthmatics and non-asthmatics should not differ. The correlation between the degree of asthma and the anaerobic work capacity should indicate whether asthma as such is a limiting factor for physical activity. Anaerobic exercise lasts less than 2 minutes while exercise-induced asthma only manifests after 6 minutes.

\section{Study structure}

A case controlled study was carried out on 41 white children (21 asthmatics and 20 healthy children) between the ages of 13 and 18 years, selected from 3 high schools in the northern suburbs of Cape Town by means of a random test.

The test subjects had to comply with the following criteria:

\section{Cases:}

- Male or female

- 13-18 years

- Must attend High Schools A,B or C, which are representative of high schools in the northern suburbs of Cape Town

- Grade I, II, or III asthmatics

- One or more asthma attacks in the past 12 months

- No upper airways diseases for at least 6 weeks before testing

\section{Controls:}

- Must attend High Schools A, B or C, which are representative of high schools in the northern suburbs of Cape Town

- The same age, sex and height, $\pm 2 \mathrm{~cm}$, as the test group.

\section{Figure 1: Gradire of asthma according to clinical history}

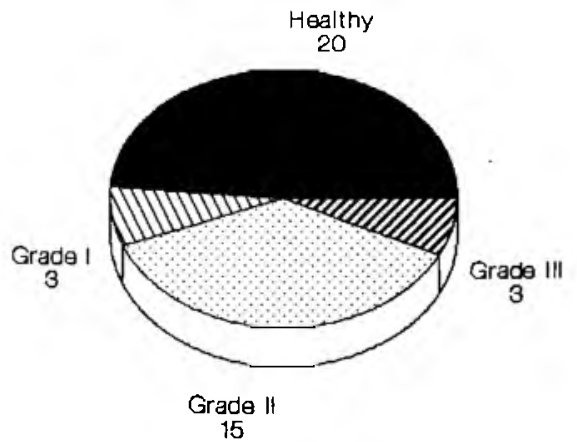

\section{Procedure}

Each prospective subject completed a clinical questionnaire from which the degree of asthma was established (Figure 1). It was then decided whether the subject satisfied the criteria for inclusion.

Next, three variables were measured, viz. percentage body fat, pulmonary functions and fitness.
The percentage body fat was determined by anthropometric measurements, viz. height, mass, bi-epicondylar measurement and skinfolds. Spirometric measurements for determination of forced expiratory volume $\left(\mathrm{FEV}_{1}\right)$, forced vital capacity (FVC) and peak expiratory flow rate (PEFR) were carried out by means of a Minnato Autospiro before and after a fitness test.

The fitness test consisted of six isotonic exercises in the form of a circular programme, i.e. sit-ups, upright bounces, push-ups, walking test, short runs and "burpees". Because the anaerobic work capacity was being measured by high impact isotonic exercise of less than 2 minutes duration, each exercise lasted only 30 seconds with a rest period of two minutes between each station.

Fifteen seconds after the subject completed a station, his/her pulse was taken for $\mathbf{3 0}$ seconds.

\section{RESUILTS}

The anthropometric measurements, spirometry and fitness test yielded the following results.

\section{Anthropometry:}

The difference between the asthmatics and the control group's parameters was not statistically significant - specifically also not on the percentage body fat.

\section{Spirometry:}

Al the pre-exercise values of the asthmatics were lower than those of the control children. There were, however, two whose values were statistically significantly lower i.e. the volume relationship (FEV 1 /FVC\%) and the flow times 50 (F50) (Table 1). After completion of the fitness test there was again a significant drop in the FEV $1 / F$ V $\%$ and F50 of the asthmatics and also in their FEV (Table 2).

\begin{tabular}{|c|c|c|c|}
\hline TABLE & 1: & PRE-EXERCISE & SPIROMETRY \\
\hline 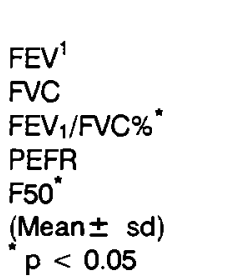 & & $\begin{array}{c}\text { Asthma } \\
2.87 \pm 0.55 \\
3.59 \pm 0.65 \\
80.10 \pm 8.08 \\
6.65 \pm 1.30 \\
3.10 \pm 0.98\end{array}$ & $\begin{array}{c}\text { Control } \\
3.18 \pm 0.73 \\
3.68 \pm 0.85 \\
86.61 \pm 5.10 \\
6.96 \pm 1.76 \\
4.07 \pm 1.07\end{array}$ \\
\hline
\end{tabular}

TABLE 2: SPIROMETRY AFTER EXERCISE (pre-post)

$\begin{array}{lcc} & \text { Asthma } & \text { Control } \\ & \text { FEV } & \\ \text { FVC } & -7.55 \pm 14.00 & 0.68 \pm 3.36 \\ \text { FEV }_{1} / \text { FVC\% }^{\star} & -5.31 \pm 10.76 & -1.33 \pm 4.27 \\ \text { PEFR } & -2.77 \pm 6.19 & 2.10 \pm 2.57 \\ \text { F50 } & -8.80 \pm 17.54 & -1.44 \pm 8.10 \\ \text { Mean }^{\star} & -23.30 \pm 41.04 & 1.00 \pm 6.44 \\ \text { p sd) } & & \end{array}$

Six of the 21 asthmatics showed a drop of more than $10 \%$ in their FEV 1 after the fitness test. They therefore had a positive response to exercise and could be considered to be exercise-induced asthmatics.

\section{Fitness test:}

The anaerobic work capacity was calculated by adding together the total number of attempts at all 6 stations and, while there was no statistically significant difference, the asthmatics recorded fewer attempts per exercise than the control children.

The hear rate of the asthmatics during the fitness test was uniformly higher than that of the control children, indicating greater effort. These differences, however, were again not statistically significant (Figure 2). 

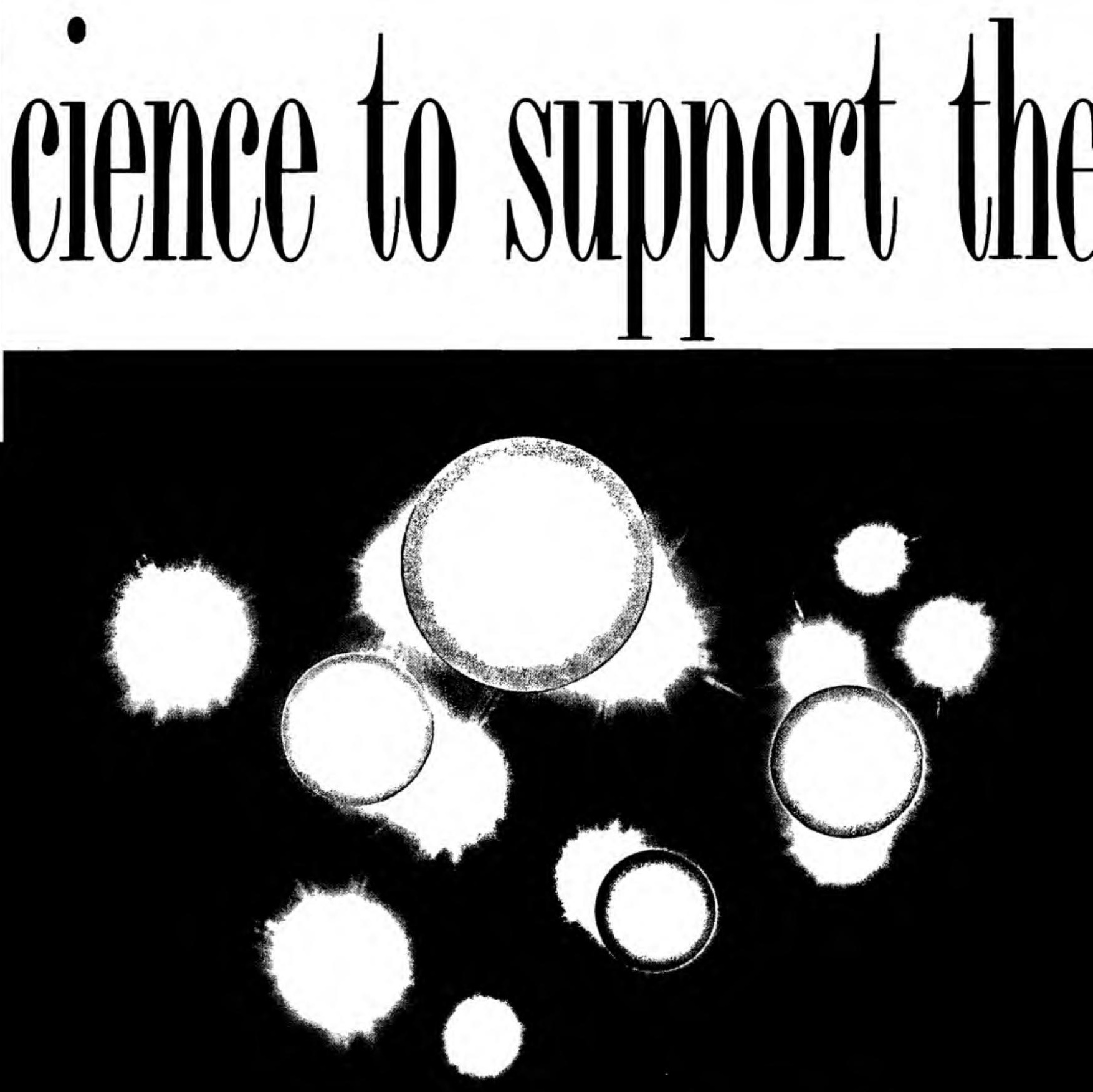

Boehringer Ingelheim nebulising solutions

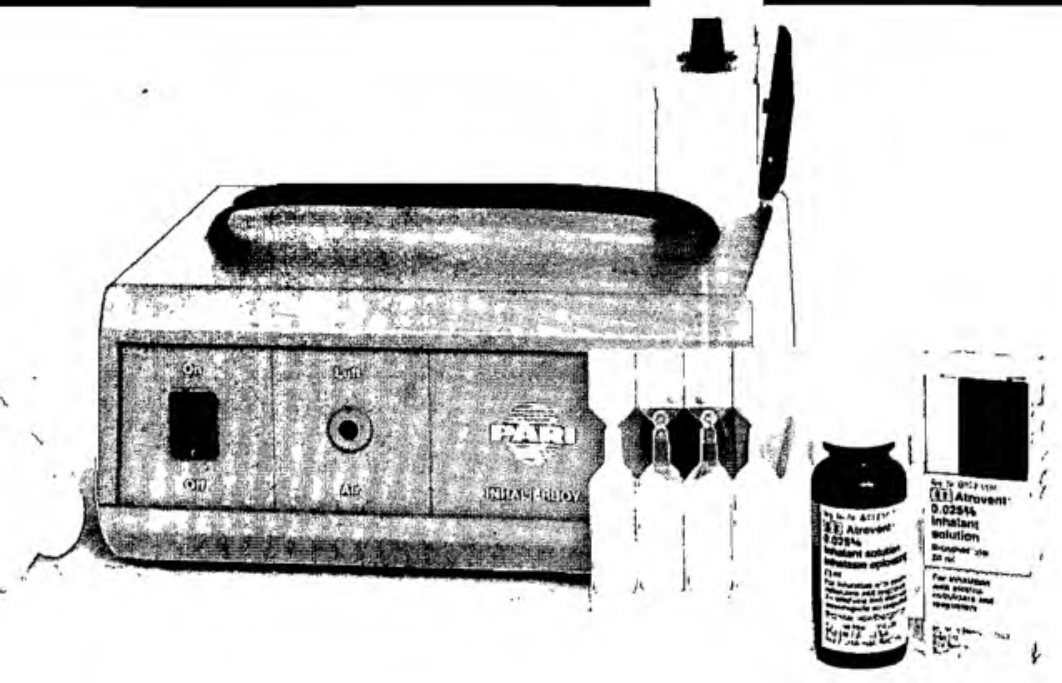




\section{Flgure 2: Hearl rabe response of esthma outherers and controte}

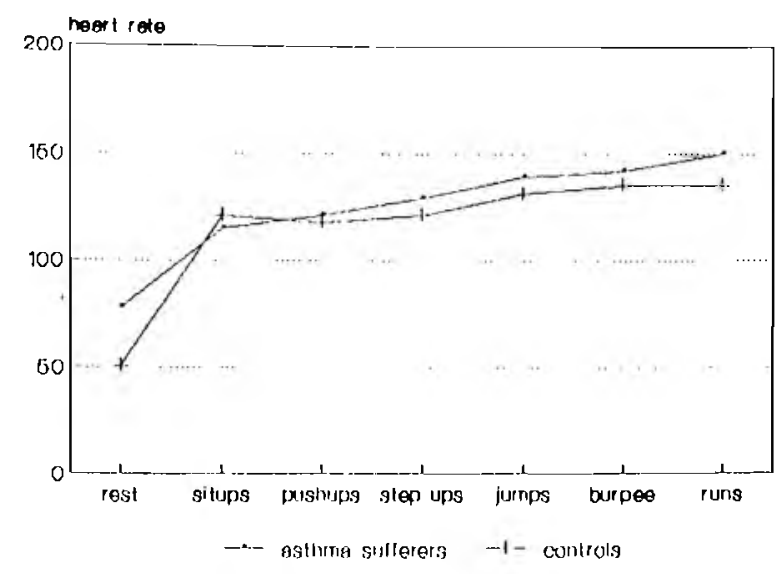

\section{DISCUSSION}

The results of this study demonstrate very clearly that the anaerobic working capacity of asthmatics is not restricted. liactors such as their percentage body fat and the degree of asthma did not play a limiting role in their exercise ability. This implies that the majority of asthmatics can lead a normal and active life and, as far as fitness is concerned, need not defer to normal, healthy children.

From the above it follows that the role of the physiotherapist should be not so much on the physical side as on the psychosocial implications of regular exercise and hence the total rehabilitation of the asthmatic. Asthmatics and their parents should be given information about the daily treatment of the disease (asthma) on the physical and psychological levels.

From the literature ${ }^{15.16}$ it is also apparent that more researchers support the view that the psychosocial benefits of regular sport and relaxation are more advantageous for the asthmatic than the physical advantages.

A primary shortcoming of this study is the fact that most of the asthmatics suffered from grade II asthma. To obtain a true correlation which would be both clinically and statistically meaningful, a larger test group is needed.

The lack of appropriate references in the literature regarding the anaerobic work capacity of asthmatics meant that the results of this study could not be compared with previous studies. The present study should therefore make a valuable contribution.

Because asthmatics already have limited pulmonary function during rest, the significant differences in lung function between the asthmatics and the control group after exercise were not unexpected. In contract to the literature ${ }^{3}$ which indicates that uninterrupted exercise of at least 6 minutes is needed to produce the typical asthmatic response, it was found in this study that interrupted exercise of less than 6 minutes can also cause exercise-induced bronchospasm (EIB). However, it appears that his bronchospasm response to anaerobic activities is confined to serious (Grade III) asthmatics, since only 6 of the 21 asthmatics showed a drop of more than I0\% in FEV $_{1}$ after the fitness test

Asthmatics with EIB developed a significantly greater change in pulmonary function after the fitness test than asthmatics without EIB.

The reasons why only some of the asthmatics developed bronchospasm during anaerobic activity is not obvious. A possible explanation might be that only serious asthmatics (Grade III) will develop EIB during anaerobic activity. According to the clinical battery only 1 child who developed EIB was a grade III asthmatic, while two were grade I and three were grade II asthmatics. On the one hand these findings draw attention to the fact that a clinical history is not an objective measure of the true nature and range of asthma and that asthma is often under-diagnosed. On the other hand this study might indicate a subgroup of asthmatics who develop bronchospasm with anaerobic types of activity as well.

\section{Anaerobic Work Capacity}

The findings of this study cannot be compared with others because no related literature could be found. The little literature which does deal with anaerobic work capacity and fitness has one main shortcoming, viz. the quantification of anaerobic work capacity. Moreover, fitness tests differ in the content of the exercise battery, making comparison of the existing literature impossible.

Although the "fitness test" used in this study is not an official test for anaerobic work capacity, it consisted of six isotonic exercises which test the work capacity of all the large muscle groups. The rescarchers therefore believe that this test is a good indicator of anaerobic work capacity.

The results show that there is no significant difference in the anacrobic work capacity of asthmatics and a control group. Since the asthmatics rccorded a smaller number of attempts per exercise, howcver, it could bc that the opposite might be demonstrated with a larger test group.

The results also show a non-significant difference in the anacrobic work capacity of asthmatics with EIB and those without. Bccause the pulmonary functions of the asthmatics with EIB showed that these children developed bronchospasm with excrcise, it is assumed that these children must have a particularly high motivation to reach the same work capacity as non-asthmatics.

Accordingly, the researchers concluded that only serious asthmatics develop bronchospasm with anacrobic activity, but that this has no detrimental effect on their anaerobic work capacity.

\section{CONCLUSIONS}

The researchers came to the conclusion that there was no difference between the anaerobic work capacity of the asthmatics and the control children, which means that this form of activity is more advantageous for the asthmatic. However, acute asthmatics will still show a positive response to this type of exercise.

The percentage body fat and the grade of asthma are also not limiting factors during anacrobic exercise.

In addition, there was a poor correlation between the percentage body fat, pulmonary function and fitness.

A clinical history is not an objective measure of the degree of asthma and an exercise test is necessary to establish the genuine nature and extent of the disease.

It is general practice for the asthmatic or his parents to complete a clinical battcry according to which the patient is then classified as a grade I, grade II or grade III asthmatic. The asthmatic is then subjected to an aerobic fitness test of $10-12$ minutes on a treadmill, which is stressful for the patient and may also be time-consuming.

In contrast a general practitioner can subject the asthmatic to an anacrobic fitness test which is less stressful, can be done anywhere at any time, requires no apparatus and takes little time.

\section{REFERENCES}

1. Hurt M. Physical conditioning in asthma. Ann Allergy 1964; 22:229-237. 2. Morton AR, Fitch $\mathrm{KD}$, Hahn AG. Physical activity and the ast hmatic. The Physician and Sports Medicine 1981; 6:51-64.

3. Marley WP. Asthma and Excrcise, a review. Am Corr Ther J 1977 (July August).

4. Terblanche E. Die voorkoms van oefenings-geïnduseerde brongospasma onder kinders en die effek daarvan op hulle funksionele status. MSc Thesis, University of Stellenbosch, 1988.

5. Walter R, Frontera MD, Richard P, Adams PD. Endurance Exercise: Normal Physiology and Limitations Imposed by Pathological Processes (Pan 1). The Physician and Spons medicine 1986; 14(8):94-104.

6. Tecklin JS. Physical Therapy for Children with Chronic Lung Disease. Phys Ther 1981; 61:1774-1781.

7. Fitch KD, Godfrey S. Asthma and Athletic Performance. JAMA 1976; 236:152-157.

8. Khan AU, Olson DL. Physical Therapy and Exercise-Induced Bronchospasm. Phys Ther $1975 ;$ 55:878-880.

9. Fridberg S, Bevegard S, Graff-Lonnevig V, Hallbäck I. Asthma from 
childhood until adulthood. A follow-up study of 20 subjects with special reference to work capacity and pulmonary gas exchange. J Allergy Clin Immunol 1989; 84(2):183-190.

10. Christie D. Physical training in chronic obstructive lung disease. $\mathrm{Br} \mathrm{Med}$ $J$ 1968; 2:150-151.

11. Cockcroft AE, Saunders MJ, Berry G. Randomised controlled trial of rehabilitation in chronic respiratory disability. Thorax $1981 ; 36: 200$ 203

12. McGavin CR, Gupta SP, McHardy GJR. Twelve minute walking test for assessing disability in chronic bronchitis. $\mathrm{Br} \mathrm{Med} \mathrm{J} \mathrm{1976;} \mathrm{1:822-823.}$

13. McGavin CR, Gupta SP, Lloyd EL, McHardy GJR. Physical rehabilitation for the chronic bronchitic: results of a controlled trial of exercises in the home. Thorax $1977 ; 32: 307-311$.

14. Mungall IPF, Hainsworth $R$. Assessment of respiratory function in patients with chronic obstructive airways disease. Thorax 1979; 34:254 258.

15. Sly MR, Harper RT, Rosselot I. The effect of physical conditioning upon asthmatic children. Ann Allergy 1972; 30:86-94.

16. Booker HA. Exercise Training and Breathing Control in Patients with Chronic Airflow Limitations. Physiotherapy 1984; 70(7):258-260.

\section{CLASSIFIED ADVERTSEMENTS GEKLASSIFISEERDE ADVERTENSIES}

\section{LOCUM AVAILABLE \\ PLAASVERVANGER BESKIKBAAR}

Locum available for work in Durban, Cape Town or Johan nesburg, from June to August 1991: full doys

Telephone (031) 23-2308 (w), (031) 52-2198 (h).

NOORDLIKE

\section{PRACTICES FOR SALE}

PRAKTYKE TE KOOP

Praktyk te koop. Gevestigde praktyk in mediese sentrum. KONIAK: Hanneli Strasheim: Telefoon [012) 55-6759(w) (012) $57-6377(\mathrm{~h})$

PRETORIA, EASTERN SUBURBS

Well established practice for sale in this growing area! Fully equipped - pleasant surroundings.

CONTACT: Mrs A Bolsens (012) 64-2161 after hours.

\section{EQUIPMENT FOR SALE}

\section{APPARAAT TE KOOP}

Bird Mark 8 Respirator plus various accessories (nebulisers, masks, oxygen regulator, instruction and various booklets etc.). Price: R2,800.

CONTACT: Mr W P Roets (03931) 74225

\section{BETHLEHEM}

Tru-Trac traksie, Medeci Interferensie, Ultraklank, Devilbiss, Minidyne

KONTAK: Kara Pellissier (01431) 32163.

\section{PREMISES TO LET \\ PERSELE TE HUUR}

CAPE TOWN

Consulting rooms to let in occupational therapy practice in Kenilworth

CONTACT: Hilary Henderson (021) 61-7834 or (021) 61-5435.

\section{BRYANSTON}

Medical Suite available to share with dentist. Fully

equipped and staffed in Bryanston.

CONTACT: Dr A van der Walt (011) 706-7704(w)

NOTICES
KENNISGEWINGS

CYRILDENE

Freda Storger wishes to inform her colleagues that the tele- phone number that appeared in the new private practitioners booklet is incorrect.

The new telephone number is (011) 453-8176. Freda respectfully asks all members to change this number in their booklet.

\section{GRABOUW}

Jeanine van der Merwe wil graag haar kollegas in kennis stel dat sy haar praktyk geopen het te Grabouw.

Telefoon (024) 594603.

\section{courses \\ KUPSUSSE}

\section{REFRESHER COURSE}

DATES: 13 - 30 MOY 1991

VENUE: Johannesburg Hospital, Physiotherapy Department ENQUIRIES: Miss P Blake (011) 488-3210, (011) 488-4210.

\section{ORTHO-PAEDIATRIC EXERCISES FOR BABIES}

Course in Johannesburg by Agnes Wenham: "Physiotherapy for Mother and Child". Limited to 6 participants. Tuesdays and Thursdoys 9.30 to $11.30,6$ August to 12 September 1991. Fee R600.

27 Sixth Avenue, Parktown North 2193

Telephone (011) 788-5028.

ACUPUNCTURE COURSE MODULE I

Presented by the Private Practitioners Association Northem

Transvaal Branch

VENUE: Jakaranda Hospital, Muckleneuk, Pretoria

DATES: 15 and 16 June 1991

FEES: SASP Members: R250; Non-Members R350.

Please send your application, together with the appropriate fee to the Treasurer, $P O$ Box 14513, Verwoerdburg 0140.

ENQUIRIES: (012) 628-9654 or (012) 63-1638.

THE HOLISTIC APPROACH TO THE KNEE JOINT

Presented by Southern Transvaal

DATES: 29 and 30 June 1991

VENUE: Johannesburg Hospital Physiotherapy Department

FEE: SASP Members: R250; Non-Members R350;

Cancellation fee: R100.

Limited to 40 participants

Teas and lunches included.

Please send your application, together with the appropriate fee to Caren Fleishman. 20 John Mackenzie Drive, Em-

marentia 2195

ENQUIRIES: Caren Fleishman (011) 884-1981 (w) or lan Seels (011) 442-7641 (h).

\section{WORK IN THE UNITED STATES}

\section{PHYSIOTHERAPISTS EXCELLENT JOBS}

We handle all licensure and visa paperwork. Minimum commitment of one year required. TRN fees paid by employer Write or phone collect:

\section{THERAPY RESOURCE NETWORK P O BOX 5430}

Plymouth, Michigan 48170, USA

Phone (313) 455-6660 